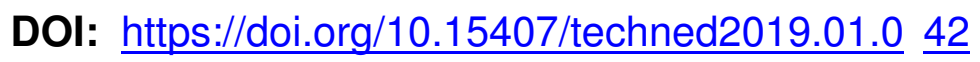

\title{
DETERMINATION OF THE OSCILLATING POWER IN ASYMMETRICAL NON-SINUSOIDAL MODES OF ELECTRIC NETWORKS
}

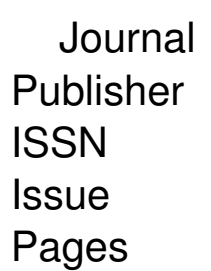

Tekhnichna elektrodynamika Institute of Electrodynamics National Academy of Science of Ukraine 1607-7970 (print), 2218-1903 (online)

No 1, 2019 (January/February)

$42-49$

\section{Authors}

\section{M.J. Burbelo ${ }^{1 *}$, A.V. Hadai ${ }^{2 \star *}$, O.V. Stepura ${ }^{3}$}

1 - Vinnytsia National Technical University,

95 Khmelnytske shose, Vinnytsia, 21021, Ukraine,

e-mail: burbelomj@gmail.com

2 - Lutsk National Technical University,

str. Lvivska, 75, Lutsk, 43018, Ukraine,

e-mail: haday@meta.ua

3 - ITC "Energy Accounting" Ltd.,

str. Pirogova, 151 A, Vinnytsia, 21008, Ukraine,

e-mail: Stepua74@gmail.com

* ORCID ID : http://orcid.org/0000-0002-4510-2911

** ORCID ID : http://orcid.org/0000-0002-4195-7218

\section{Abstract}


The paper consideres electro-technological installation electricity network. Voltage source contains the basic, fifth and seventh harmonic components of voltage with simultaneous unsymmetry of one phase, and loading is the source of current with the indicated harmonic components. The components of instantaneous power from unsymmetry are determined as instantaneous conditional powers of reverse sequence. These powers are of non- sinusoidal character that testifies to mutual impact of the all harmonic components from different sequences. Pulsating power is written in through the sum of powers predetermined by unsymmetry and non-sinusoidal character. Component powers of reverse sequence and power of harmonic distortions are determined by integration of corresponding instantaneous powers on the period of $T$ supply voltage. The pulsations levels of active and reactive powers are appraised according to the root-mean-squares of pulsation powers. The pulsations level of component powers from loading unsymmetry is appraised by means of root-mean-squares of reverse sequence conditional powers. Components of distortion complex power are determined by integration of the distinguished sixth harmonic component of instantaneous powers for distortion in the period of T supply voltage. From the other side the complex values of distortion powers are determined as vectorial product of vectors of tension complex and separate sequences currents. Exactness of powers determination depends on taking into account the tension and reverse sequence current. Analysis of components vibrations for active and reactive powers, predefined by non-sinusoidal character, showed the presence of component powers of the twelfth harmonic component. Their level does not exceed $1 \%$ powers of the sixth harmonic component that is why its influence is possible to be ignored. Offered dividing of pulsating power into two components gives an opportunity to define reasons of indexes worsening of electric power quality in case of the asymmetrical non- sinusoidal loading composition. References 20, figures 3.

Key words: electrical networks, asymmetric sinusoidal mode, the definition of a oscillating power.

Received: 05.04 .2018

Accepted: 08.08 .2018

Published: 10.01 .2019 


\section{References}

1. Shydlovskyi A.K., Kuznetsov V.H. Improving power quality in electrical networks. Kyiv: Naukova dumka, 1985. 268 p. (Rus)

2. Krogeris A.F., Rashevits K.K., Treimanis Je.P., Shinka Ja.K. Power AC. Riga:

Fiziko-energeticheskii institut Latviiskoi Akademii Nauk, 1993. 294 p. (Rus)

3. Melnikov N.A. Reactive power consumption in the network of electrical. Moskva: Energiia, 1975. 128 p. (Rus)

4. Akagi H., Watanabe E.H., Aredes M. Instantaneous power theory and applications to power conditioning. IEEE Press, Willy-Interscience, 2007. 379 p. DOI: https://doi.org/10.1002/047011 8938

5. Czarnecki L.S. Constraints of the Instantaneous Reactive Power p-q Theory. IET Power Electronics

2014. Vol. 7. No 9. Pp. 2201-2208.

DOI:

https://doi.org/10.1049/iet-pel.2013.0579

6. Watanabe E.H., Stephan R.M., Aredes M. New concepts of instantaneous active and reactive powers in electrical systems with generic loads. IEEE Trans. Power Delivery. 1993. Vol. 8. No 2. Apr. Pp. 697-703. DOI:

https://doi.org/10.1109/61.216877

7. Watanabe E.H., Aredes M., Akagi H. The p-q theory for active filter control: some problems and solutions. Revista Controle \& Automacao. 2004. Vol. 15. No 1. Pp. 78-84. DOI: https://doi. org/10.1590/S0103-17592004000100010

8. Nabae A., Tanaka T. A new definition of instantaneous active - reactive current and power based on instantaneous space vectors on polar coordinates in three-phase circuites. IEEE Transactions on Power Dilivery

. 1996. Vol. 11. No 3. Pp. 1238-1244.

9. Czarnecki L.S. Comments on active power flow and energy accounts in electrical systems with nonsinusoidal waveforms and asymmetry. IEEE Transaction on Power Divelery. 1996. Vol. 11, No 3. Pp. 1244-1250.

10. Czarnecki L.S. On some misinterpretations of the instantaneous reactive power $p-q$ theory. IEEE Trans. On Power Electronics

. 2004. Vol. 19, No 3. Pp. 828-836. DOI:

https://doi.org/10.1109/TPEL.2004.826500

11. Czarnecki L.S. Effects of supply voltage asymmetry on IRP p-q theory based switching compensator control. IET Power Electronics. 2010. Vol. 3. No 1. Pp. 11-17. DOI: https://doi.or g/10.1049/iet-pel.2008.0079

12. Tolbert L.M., Halbetler T.G. Comparison of time based non-active power definitions for active filtering. Power Electronics Congress. Acapulco, Mexico. 2000. Vol. 1. Pp. 73-79.

13. Kale M., Ozdemir E. Harmonics and reactive power compensation with shunt active power filter under non-ideal mains voltage. Electric Power Systems Research. 2005. Res 77. Pp. 363-370.

14. Kolb A.A. Group power supply systems for drives with capacitive accumulators and parallel active filters. Elektrotekhnichni ta kompiuterni systemy. 2011. Vol. 03(79). Pp. 404-407. (Rus). 
15. Andrzej Firlit. Power Theory with Non-sinusoidal Waveforms. Annex 3. John Wiley \& Sons, Ltd. 2008. Pp. 27-51.

16. Burbelo M.Y., Hadai A.V. Determination of three-phase nonlinear loads electric. Kompiuter no-intehrovani tekhnolohii: osvita, nauka, vyrobnytstv

o. 2016. No 24-25. Pp. 61-67. (Ukr).

17. Burbelo M.Y., Hadai A.V., Melnychuk S.M., Loboda Yu.V. Determination of capacities of loads of three-phase electric networks in nonsinusoid and asymmetric modes. Visnyk

Vinnytskoho politekhnichnoho instytutu

. 2017. No 1. Pp. 51-56. (Ukr).

18. Burbelo M.Y., Melnychuk S.M., Nykytenko M.V. Measurement of parameters of asymmetrical quick-change three-phase loadings. Tekhnichna Elektrodynamika. 2011. № 2. Pp. 54-56. (Ukr).

19. Burbelo M.Y., Melnychuk S.M. Determination powers at unsymmetrical modes of three-phase networks with grounded neutral. Tekhnichna Elektrodynamika. 2015. No 4. Pp. 71-75. (Ukr).

20. Pukhov G.E. Power Systems Theory periodic multiphase currents. Elektrichestvo. 1953. No 2. Pp. 56-61.

\section{$\underline{\text { PDF }}$}

